\title{
STUDY OF PEG-6000 EFFECT ON GROWTH AND PHYSIOLOGICAL PARAMETERS OF CHINA ASTER (CALLISTEPHUS CHINENSIS) AND STRAWFLOWER (HELICHRYSUM BRACTEATUM) IN IN VIVO CONDITIONS
}

\author{
Zapryanova N. G. \\ Institute of Ornamental and Medicinal Plants, \\ Sofia, Bulgaria, e-mail: nadejda_zaprianova@abv.bg
}

\begin{abstract}
Drought stress is one of the most important environmental factors in reduction of growth, development and production of plants. In our study, in order to simulate water deficit induced by osmotic stress, different concentrations of polyethylene glycol (PEG) 6000 were used: $10 \%, 20 \%$ and $40 \%$. The goal of the investigation is to establish the growth and physiological response of annual flowers (Callistephus chinensis L. and Helichrysum bracteatum) to drought. Seedlings from Callistephus chinensis L. and Helichrysum bracteatum react individually on the simulated drought stress, using PEG in controlled (in vivo) conditions - the detected water deficit varies between $49.9 \%$ to $63.12 \%$ - at $40 \%$ PEG. Changes were identified in the seedling growth, cell membrane stability and the RWC in plant tissues, corresponding to the stress duration and increase of the PEG concentration. The usage of $40 \%$ for 6 days was the maximum admissible for the seedlings from Callistephus chinensis L. and Helichrysum bracteatum, based on the low percentage of plants which regained their development.
\end{abstract}

Key words: Callistephus chinensis L., Helichrysum bracteatum, polyethyleneglycol (PEG), water deficit, relative water content (RWC, \%), conductivity.

According to the climatic forecasts, rainfalls in Southeast Europe, are expected to increase in winter and decrease during the warm months of the year in the 21 st century. The results from a number of projects show that this is also true for the Balkan Peninsula (CC-WARE, 2014; CC_WaterS, 2012; CECILIA, 2011). The established decrease of precipitation as well as the increase of air temperature range has led to the deterioration of the climatic conditions in Bulgaria. According to the results of CC-WARE and the River Water Management Plan 2016-2020, there is a permanent drought tendency in the area $[15,24]$. The climate change causes stress on the plants that reduces the growth, development, and yield and production quality.

Drought stress is one of the most important environmental factors in reduction of growth, development and production of plants [17]. Each studied genotype 
reacts differently to water stress, and even within one species there is a significant change in tolerance to drought [8]. The research on the physiological mechanisms of plant resistance in laboratory conditions gives an opportunity to monitor the specific response of the plants to one of the impact factors [2].

The use of PEG allows to recreate the necessary osmotic potential i.e. the to simulate soil drought $[18,19,26,28]$. Water deficiency in plants occurs due to the inaccessibility of water due to the reduced osmotic (aqueous) potential of the nutrient medium containing dissolved PEG. In this way, the drying of the plants is simulated, and the high molecular weight of the polymer impedes its entry into the tissues [7].

Several authors report that studies have been conducted on the physiological and adaptive response to simulated water deficiency in vivo and in vitro conditions on ornamental plants [3, 4, 16, 21, 23, 29, 30, 31]. Relative water content (RWC) was used as a measure of drought. This index may be useful for determining the plant leaf water status. The following indicators have been used to identify the water status of plants and disrupt the organization and composition of cell membranes: growth, relative water content (RWC) [12, 20, 29] and increased electrolyte loss, established by conductometry [10]. Scientific studies on the response of annual flowers to water deficit are limited [11]. The work is mainly concentrated in botanical gardens.

The group of annual ornamental species, also known as "summer" flowers, are the main crops for planting parks and gardens, and for cultivation for cut flowers. They are the most affected by high temperatures and water scarcity because they are grown in open areas, their blooms coincide with summer heat and the root system is shallowly located.

Callistephus chinensis (L.) Nees and Helichrysum bracteatum (Venten.) Willd. are plants in the family Asteraceae [5,25]. They are annual ornamentals plants grown in gardens and are important for the floriculture industry for production cut flowers. The purpose of the investigation was to establish the growth and physiological response of the annual flowers (Callistephus chinensis and Helichrysum bracteatum) to drought.

Materials and methods. The study was conducted at the Institute of Ornamental and Medicinal Plants -Sofia with annual flowers - aster (Callistephus chinensis), genotype from the Princess group and helihrizum (Helichrysum bracteatum) - Asteraceae.

The trials were carried out on plants grown from seeds sown in March. The seedlings used in the experimental production were in the 5-6 leaf stage.

Water stress was simulated by polyethelene glycol (PEG) with molecular weight (MW) 6000 (Duchefa Biochemie, Netherlands). Water was used as control in our experiments. 
Глава 6. Физиология и биохимия растений

The seedlings were placed in tubes, which are pre-allocated with $50 \mathrm{ml}$ of water (control) and aqueous solution causing stress, including PEG (10 \%, $20 \%$ and $40 \%$ ), 10 for each concentration and control in 3 replicates.

The exposure duration was six days. In in vivo research, growth was expressed as the percentage of seedlings' weight increase after being cultivated for a certain period (6 days) on $10 \%, 20 \%$, and $40 \% \mathrm{PEG}$, compared to the initial weight. The membrane damage rate was defined by the electrolyte leakage from leaves with accounting for conductivity after stress and was expressed as $\mu \mathrm{S} / \mathrm{g}$ fresh weight.

The relative water content (RWC) was measured simultaneously with electrolyte leakage and calculated by the following formula:

RWC \% = (fresh weight - dry weight $) /($ turgor weight - dry weight $) \mathrm{x}$ 100 - according to Turner's method [27].

The water deficit (WD) was expressed by the following formula:

$$
\text { WD } \%=1-\text { RWC. }
$$

After the stress period plants were transferred to clean water to establish their capacity for recovery.

The data was analyzed for significance by means of the t-test using GraphPad Prizm software. The results were statistically significantly different at $\mathrm{P}<0.05(*), \mathrm{P}<0.01(* *), \mathrm{P}<0.0001(* * *)$ and nonsignificances, as respectively, compared to the control.

Results and discussion. Data of this investigation showed that the negative effect of drought, was reflected in the parameters that indicated the plants' water status.

The reported water deficit ranged from $19 \%$ in the control plants to $49.9 \%$ (40 \% PEG) for the Callistephus, and from 17.5 to $63.12 \%$ for the Helichrysum (fig. 1). According to the concept of [9], dehydration causing plant deficiency up to $30 \%$ is considered as mild or moderate stress.

Research showed that in our experimental setting the plants were stressed in higherr concentrations of PEG. This was reflected on the results obtained for the plant's physiological indicators.

As a comparison, water deficit on Tagetes patula var. 'Usmivka' was studied in two experiment variants: $1^{\text {st }}$ in pots in a greenhouse - with reduced watering regime and $2^{\text {nd }}$ in test tubes in laboratory conditions, using different PEG concentrations. Maximum water deficit ( $72 \%$ ) in plant tissues was reported in pots, watered once a week, as well as with the usage of $40 \%$ PEG with duration of 6-day stress period. This corresponded to the highest index of electrolyte leakage and RWC in plant tissues and reduced plant growth [30,31]. 


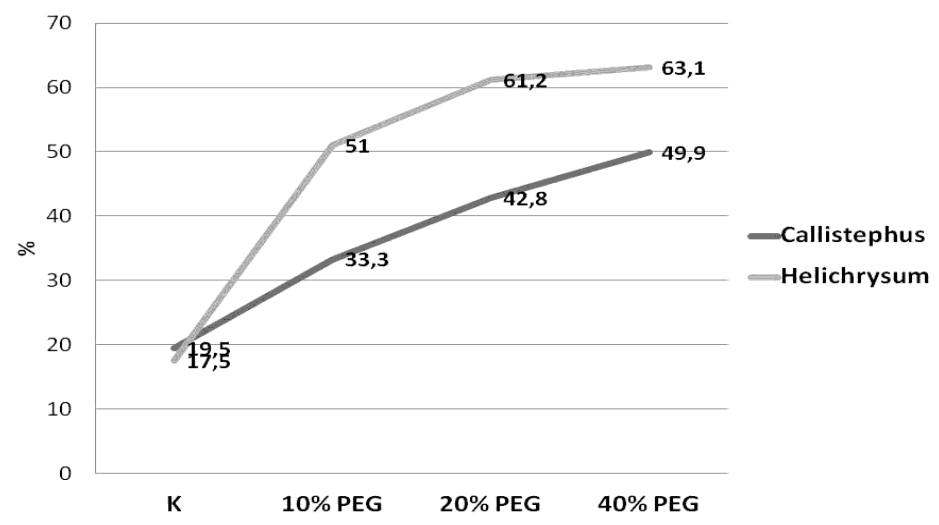

Fig. 1. Water deficit (\%)

in the plant tissues of Callistephus chinensis L. and Helichrysum bracteatum at different PEG concentrations and stress duration 6 days

The water content in the total weight of the flowers reaches about $80 \%$. For the construction of $1 \mathrm{~g}$ dry matter flowers use 300 to $800 \mathrm{~g}$ of water. The most sensitive to water shortages are the periods of growth and flowering [1]. The results show that depending on the applied concentration of polyethylene glycol, the values of the monitored parameters also change.

With PEG concentration increasing and stress time prolonging, the leaf relative water content continued to decline. Data in fig. 2 revealed that addition of PEG affected significantly the growth of seedlings from Callistephus and Helichrysum.

The seedling grown in the control environment increased their size slightly to $110.1 \pm 2.1 \%$ for Callistephus and $88.9 \pm 5.8 \%$ for Helichrysum. With the increasing the PEG concentration, growth decreased proportionally in all tested varieties with statistical significance of $\mathrm{P}<0.0001 * * *$ (fig. 2).

Growth inhibition was found in the both ornamental species, but lower value was recorded for Helichrysum - $22 \%$. Compared to the control sample, the decrease was $60 \%$.

The same tendency was found in Tagetes 'Usmivka' variety. With the increasing of PEG concentration in culture medium, the growth of the explants in vitro decreased proportionally. At concentration of $30 \%$ and $40 \%$ PEG the growth was below $50 \%$ compared to the control [31].

When comparing the results of RWC, simulated drought reduces the RWC in plant cells in the both studied ornamental species - Callistephus and Helichrysum (fig. 3). 


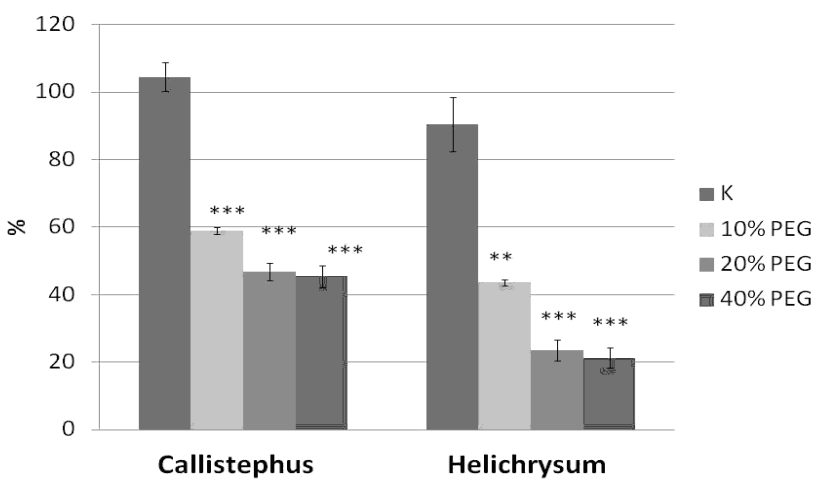

Fig. 2. Growth of Callistephus chinensis L. and Helichrysum bracteatum at different PEG concentrations and stress duration 6 days

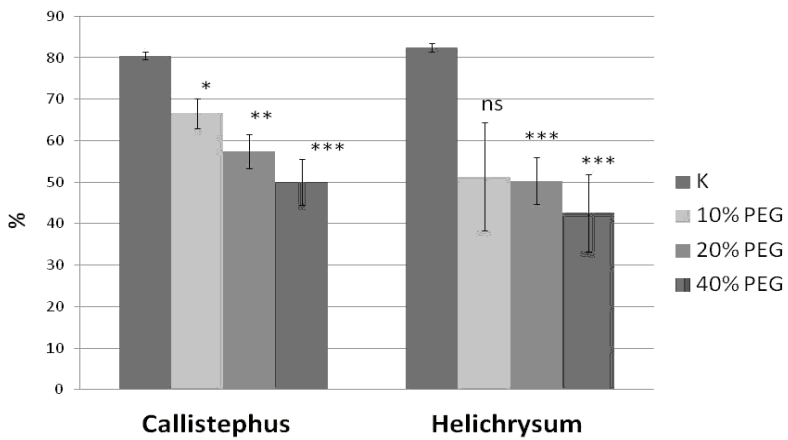

Fig. 3. Relative water content (RWC \%)

of Callistephus chinensis L. and Helichrysum bracteatum at different PEG concentrations and stress duration 6 days

The measured values of relative water content (RWC \%) show high percentage of water content in the tissues of the control plants $-80-82 \%$. The lowest values of \% RWC in plant tissues were obtained at $40 \%$ PEG for both Callistephus and Helichrysum, $50.05 \%$ and $42.6 \%$, respectively. Different plant species may have the same RWC values with different amounts of water in their leaves due to the difference in turgor weight and dry weight according to [6]. Changes in the RWC were probably caused due to the structural functional changes ensuring the adaptation of plants to drought. 
Studies on the drought resistance of Amaranthus plants show that in the control plants, the RWC kept a high rate of tissue water content. For instance, the RWC of $A$. tricolor was between $83 \%$ and $92 \%$ and 86-94 \% in Amaranthus cruentus. Stress had caused a significant change in the reported values, and this indicator in Amaranthus tricolor decreased up to $58 \%$ and for $A$. cruentus up to $60 \%$ [23].

The disturbances in the cell membranes due to the action of the high concentration of PEG, are reflected in the increase of the measured conductivity values, which for the Callistephus reach up to $1203 \mu \mathrm{S} / \mathrm{g} \mathrm{FW}$ and for the Helichrysum $1674 \mu \mathrm{S} / \mathrm{g} \mathrm{FW}$ (fig. 4).

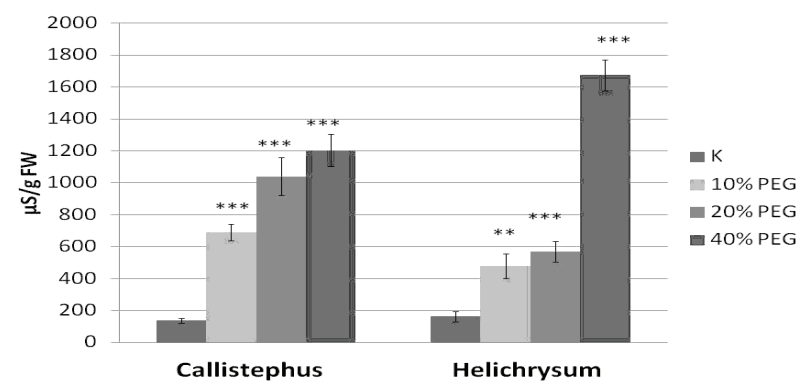

Fig. 4. Electrolyte leakage of Callistephus chinensis L. and Helichrysum bracteatum at different PEG concentrations and stress duration 6 days

There is a very significant positive correlation between membrane permeability and stress level. This effect was increased as drought stress levels enlarged according to [14]. In this connection, many studies have pointed that the cell membranes are the initial sites of the stress injury and are damaged drastically by environmental stress [22]. Leakage will vary in relation to the membrane's abilities to take up and retain solutes and thus will reduce changes in both membrane potentials and membrane permeability [13].

Simulated drought in vitro, using different concentrations of polyethylene glycol $6000(10 \%, 20 \%, 30 \%$ and $40 \%)$, induced changes in Tagetes cell membranes. Highest electrolyte leakage rates were recorded at 6 th day $4625 \pm 521 \mu \mathrm{S} / \mathrm{g}$ FW at $40 \%$ PEG [31]. After a period of stress on the PEG concentration, Callistephus and Helichrysum seedlings were placed for recovery in water. The transfer of the plants after 6 days from PEG solutions to pure water, showed a resumption of growth of $100 \%$ for the plants that were placed at lower concentrations of PEG. For those that were in $40 \%$ PEG solutions, single plants regained their development. The seedlings of 
Глава 6. Физиология и биохимия растений

Callistephus chinensis L. showed better adaptive response. The percentage of plants that regained their development was $18 \%$, while Helichrysum bracteatum regained only $10 \%$.

A similar response was observed in the long-term stress period of 6 days in vitro, unfavorable affected the Tagetes explants. Only $10 \%$ recovered plants were obtained at $40 \%$ PEG and no rooting was recorded [31].

Conclusions. The obtained results form a guideline for screening ornamental species for abiotic stresses like drought.

Changes were observed in the seedling growth, cell membrane stability and the RWC in plant tissues, corresponding to the stress duration and the PEG concentration increasing.

Callistephus chinensis L. and Helichrysum bracteatum react individually on the simulated drought stress, using PEG $(10 \%, 20 \%$ and $40 \%$ ) in controlled (in vivo) conditions. The detected water deficit varies from $49.9 \%$ to $63.1 \%$ - at $40 \%$ PEG.

The growth of the seedling proportionally decreased with the increase of polyethylene glycol concentration from $10 \%$ to $40 \%$ and the growth was below $50 \%$ at $40 \%$ PEG vs. the control sample.

The usage of $40 \%$ of PEG, used for 6 days was the maximum admissible for the seedlings from Callistephus chinensis L. and Helichrysum bracteatum, which was based on the low percentage of plants, regained their development.

\section{References}

1. Дюлгеров Д., Тодорова П. // Наръчник по цветарство - М.: Земиздат, 1976. - С. 33-35. 2. Alexieva V., Ivanov S., Sergiev I., Karanov E. Interaction between stresses // Bulg. J. Plant Physiol. Special Issue (Proceedings of the European Workshop on Environmental Stress and Sustainable Agriculture). - 2003. - P. 1-18.

3. Asrar A.A., Abdel-Fattah G.M., Elhindi K.M. Improving growth, flower yield, and water relations of snapdragon (Antirhinum majus L.) plants grown under well-watered and waterstress conditions using arbuscular mycorrhizal fungi. // Photosynthetica. - 2012. - Vol. 50(2). - P. 305-316. - doi: 10.1007/s11099-012-0024-8.

4. Asrar A.W., Elhindi K.M. Alleviation of drought stress of marigold (Tagetes erecta) plants by using arbuscular mycorrhizal fungi. // Saudi journal of biological sciences. 2011. - Vol. 18(1). - P. 93-98. - doi: 10.1016/j.sjbs.2010.06.007

5. Cantor M., Singureanu V., Erzsebet Buta. Researches concerning the diversification of Callistephus chinensis assortment at the floral collection of UASMV Cluj-Napoca // Journal of Horticulture, Forestry and Biotechnology - 2014. - Vol. 18(1). - P. 28-34. - www.journal-hfb.usab-tm.ro 6. Ceccato P., Flasse S., Tarantola S., Jacquemoud S., Grégoire J.M. Detecting vegetation leaf water content using reflectance in the optical domain // Remote sensing of environment. - 2001. - Vol. 77(1). - P. 22-33. - doi: 0.1016/S0034-4257 (01)00191-2.

7. Chazen O., Hartung W., Neumann P. The different effects of PEG 6000 and NaCI on leaf development are associated with differential inhibition of root water transport // Plant, Cell \& Environment. - 1995. - Vol. 18(7). - P. 727-735. 
8. Cicevan R., Al Hassan M., Sestras A.F., Prohens J., Vicente O., Sestras R.E., Boscaiu M. Screening for drought tolerance in cultivars of the ornamental genus Tagetes (Asteraceae) // Peer-Reviewed Open Access Journal. - 2016. - Vol. 4 - P. e2133. - doi: 10.7717/peerj.2133. 9. Cornic G., Fresneau C. Photosynthetic carbon reduction and oxidation cycles are the main electron sinks for photosystem II activity during a mild drought // Ann. Bot. - 2002. Vol. 89. - P. 887-894. - doi: 10.1093/aob/mcf064

10. Dhindsa R., Plumb-Dhindsa P., Thorpe T. Leaf senescence: correlated with increased levels of membrane permeability and lipid peroxidation, and decreased levels of superoxide dismotase and catalase // J. Exp Bot - 1981. - Vol. 32. - P. 93-101.

11. Douglas A. Bailes Selection and Use of Stress-Tolerant Bedding Plants for the Landscape // Horticulture Information Leaflet NC State University. - 1999. - https://content.ces.ncsu. edu/selection-and-use-of-stress-tolerant-bedding-plants-for-the-landscape

12. Georgieva M., Djilianov D., Konstantinova T., Parvanova D. Screening of Bulgarian raspberry cultivars and elites for osmotic tolerance in vitro // Biotechnol. \& Biotechnol. 2004. - Vol. 19/2. - P. 95-98. - doi: 10.1080/13102818.2004.10817093.

13. Hoque M.A., Arima S. Evaluation of salt damage through cell membrane stability monitored by electrolyte leakage in water chestnut (Trapa sp.) // Bulletin of the Faculty of Agriculture, Saga University. - 2000. - № 85. - P. 141-146.

14. Hua Y., Shanshan S., Yuzhu L. Effects of Drought Stress Simulated by PEG 6000 on Physiological Characteristics of Polygonatum odoratum [J]. // Journal of Northeast Forestry University. - 2012. - Vol. 40(5). - P. 43-45.

15. Ilcheva I., Georgieva D., Yordanova A. New methodology for joint assessment of drought- risk of water supply under climate change, water stress areas identification and ecological flow provision for water framework directive // Journal of International Scientific Publications, Ecology \& Safety. - 2015. - Vol. 9. - P. 413-433. - ISSN 1314-7234.

16. Ivanova I., Zapryanova N. Effects of water deficit on growth and development of gladiolus // Субтропическое и декоративное садоводство. - 2015. - Вып. 55. - С. 121-130. - ISSN 2225-3068.

17. Jaleel C., Manivannan P., Wahid A., Farooq M., Al-Juburi H., Somasundaram R., Panneerselvam R. Drought stress in plants: a review on morphological characteristics and pigments composition // Int J. Agric Biol., - 2009. - Vol. 11(1). - P. 100-105. - ISSN Print: 1560-8530; ISSN Online: 1814-9596-08-305/IGC-DYT/2009/11-1-100-105.

18. Kaur A., Sarlach R.S. In-vitro screening of Iranian Landraces (Triticum aestivum L.) at the seedling stage for water stress tolerance using Polyethylene glycol (PEG 6000. // International Journal of Environment, Agriculture and Biotechnology - 2020. - Vol. 5(1) - P. 130-135. - doi: 10.22161/ijeab.51.20

19. Larher F., Eport L.L. Petrivalsky M., Chappart M. Effectors for the osmoinduced proline response in higher plants // Plant Physiol., Bioch. - 1993. - Vol. 31(6). - P. 911-922.

20. Lawlor D.W., Cornic G. Photosynthetic carbon assimilation and associated metabolism in relation to water deficits in higher plants // Plant Cell and Environment. - 2002. - Vol. 25(2). - P. 275-294. - doi: 10.1046/j.0016-8025.2001.00814.x

21. Mohamed M., Harris P., Henderson J. In vitro selection and characterization of a drought tolerance clone of Tagetes minuta // Plant Science. - 2000. - Vol. 159. - P. 213-222.

22. Munns R., James R.A., Lauchli A. Approaches to increasing the salt tolerance of wheat and other cereals // J. Exp. Bot. - 2006. - Vol. 57. - P. 1025-1043. - doi: 10.1093/jxb/erj100 23. Omami E.N., Hammes P. Interactive effects of salinity and water stress on growth, leaf water 
Глава 6. Физиология и биохимия растений

relations, and gas exchange in amaranth (Amaranthus spp.) // New Zealand Journal of Crop and Horticultural Science. - 2006. - Vol. 34(1). - P. 33-44. - doi: 10.1080/01140671.2006.9514385.

24. Popova Z., Ivanova M., Pereira L., Alexandrov V., Kercheva M., Doneva K., Martins D. Droughts and climate change in Bulgaria: assessing maize crop risk and irrigation requirements in relation to soil and climate region // Bulgarian Journal of Agricultural Science. - 2015. - Vol. 21(1). - P. 35-53.

25. Sarmadi M., Karimi N., Palazón J., Ghassempour A., Mirjalili M. Improved effects of polyethylene glycol on the growth, antioxidative enzymes activity and taxanes production in a Taxus baccata L. callus culture // Plant Cell, Tissue and Organ Culture (PCTOC). 2019. - Vol. 137(2). - P. 319-328. - doi: 10.1007/s11240-019-01573-y.

26. Sharman K.V., Sedgley M., Aspinall D. Production of the Australian native daisies (Helipterum roseum and Helichrysum bracteatum) for the cut flower market // Australian Journal of Experimental Agriculture. - 1989. - Vol. 29(3). - P. 445-453. - doi: 10.1071/EA9890445.

27. Turner N. Techniques and experimental approaches for the measurement of plant water stress // Plant Soil. - 1981. - Vol. 58 - P. 339-366. - doi: 10.1007/BF02180062

28. Yue H., Sun S., Li Y. Effects of drought stress simulated by PEG 6000 on physiological characteristics of Polygonatum odoratum // Journal of Northeast Forestry University. 2012. - Vol. 40(5). - P. 43-121.

29. Zapryanova N. Study of the water deficit effects on the biometrical, physiological and ornamental indicators of marigold (Tagetes patula), variety 'Usmivka' // Journal of Mountain Agriculture on the Balkans. - 2015. - Vol. 18(2). - P. 388-402.

30. Changes in physiological characteristics of marigold (Tagetes patula) cv Usmivka in inducing conditions water deficit // Scientific Works of the Agrarian University. - Plovdiv. -2015. - Vol. 59 (4). - P. 243-251.

31. Zapryanova N.G., Nencheva D.M. Effect of water deficit induced by osmotic stress on bulgarian chrysanthemum cv. Zhoro in vitro // Субтропическое и декоративное садоводство. - 2013. - Вып. 49. - С. 253-259. - ISSN 2225-3068.

\section{ИЗУЧЕНИЕ ВЛИЯНИЯ ПЭГ-6000 НА РОСТ И ФИЗИОЛОГИЧЕСКИЕ ПАРАМЕТРЫ АСТРЫ (CALLISTEPHUS CHINENSIS) И БЕССМЕРТНИКА (HELICHRYSUM BRACTEATUM) В УСЛОВИЯХ IN VIVO}

Запрянова Н. Г.

\footnotetext{
Институт декоративных и лекарственных растений, г. София, Негован, Болгария, e-mail: nadejda_zaprianova@abv.bg
}

Стресс от засухи является одним из важнейших факторов окружающей среды, выражается в снижении роста, развития и производства растений. В нашем исследовании для моделирования дефицита воды, вызванного осмотическим стрессом, использовались разные концентрации полиэтиленгликоля (ПЭГ) 6000: 10 \%, 20 \% и 40 \%. Цель исследования - установить ростовые процессы и физиологическую реакцию однолетников (Callistephus chinensis L. и Helichrysum bracteatum) на засуху. Саженцы Callistephus chinensis L. и 
Субтропическое и декоративное садоводство (73)

Helichrysum bracteatum проявляют индивидуальную реакцию на имитируемый стресс от засухи, моделируемой использованием ПЭГ в контролируемых (in vivo) условиях - обнаруженный дефицит воды варьирует от 49,9 до 63,1 \% - при 40 \% ПЭГ. Были выявлены изменения в росте проростков, стабильности клеточных мембран и относительном содержании воды (ОСВ, \%) в тканях растений, соответствующие продолжительности стресса и увеличению концентрации ПЭГ. Использование 40 \% ПЭГ в течение 6 дней было максимально допустимым для проростков Callistephus chinensis L. и Helichrysum bracteatum, основываясь на низком проценте растений, восстановивших своё развитие.

Ключевые слова: Callistephus chinensis L., Helichrysum bracteatum, полиэтиленгликоль (PEG), дефицит воды, относительное содержание воды (OCB), проводимость. 